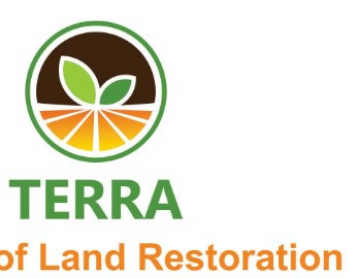

\title{
Growth and Yield of Soybean (Glycine max L. Merill) at Various Doses of Bokashi Fertilizer on Ultisol
}

\author{
Luki Rianti $^{1}$, Hesti Pujiwati ${ }^{1 *}$, Masdar $^{1}$, Hermansyah $^{1}$, Heru Widiyono $^{2}$ \\ ${ }^{1}$ Agroecotechnology Department, University of Bengkulu (Corresponding author) \\ ${ }^{2}$ Soil Science Department, University of Bengkulu \\ e-mail: hesti_pujiwati@unib.ac.id
}

\begin{abstract}
Soybean is a type of secondary crop that is widely cultivated and used as raw material for tofu, tempe, milk, and so on by the people of Indonesia. Soybean consumption is always increasing but soybean production has decreased. This study aims to obtain the optimum dose of Bokashi fertilizer on plant growth and yield in Ultisol. The study was carried out in Medan Baru, Kandang Limun Village, Muara Bangkahulu District, Bengkulu City from December 2018 to April 2019. This study used a Completely Randomized Block Design (RCBD) with one factor, namely the dose of Bokashi fertilizer with five levels, namely 0 tons $\mathrm{ha}^{-1}, 25$ tons $\mathrm{ha}^{-1}, 35$ tons $\mathrm{ha}^{-1}, 45$ tons $\mathrm{ha}^{-1}$, and 55 tons ha $\mathrm{a}^{-1}$. The results showed that the optimum dose of Bokashi fertilizer was not found in the growth component or yield component. The dose of Bokashi fertilizer had a significant effect $(p<0.05)$ on the growth of Bokashi and the number of leaves.
\end{abstract}

Keywords: soybean, Bokashi, dose, Ultisol

\section{INTRODUCTION}

Soybean (Glycine $\max (\mathrm{L}$.$) Merill) is an ag-$ ricultural commodity that is very much needed in Indonesia because it can be consumed in various processed food products such as tofu, tempeh, milk, and many other processed products (Krisnawati \& Adie, 2007). In addition to animal feed, soybeans are also used as industrial raw materials and fresheners. The nutritional content of soybeans is quite high, including $35 \mathrm{~g}$ of protein, $53 \mathrm{~g}$ of carbohydrates, $18 \mathrm{~g}$ of fat, and $8 \mathrm{~g}$ of water in $100 \mathrm{~g}$ of food, for certain varieties, the protein content of soybeans reaches 40-43 g (Suprapto, 2004). However, Indonesia has not been able to meet the needs of soybeans so that the government still imports because soybean production in Indonesia is only able to meet $30-40 \%$ of national needs (Puslitbangtan, 2012).

According to data from the Badan Pusat Statistik (2015) soybean production in 2013 was 779,992 tons of dry beans, a decrease of 63,161 tons $(7.49 \%)$ compared to 2012. According to BPS (2015), Bengkulu Province's soybean production was 5,598 tons of dry soybeans, compared to by 2014 soybean pro- duction in Bengkulu Province in 2015 decreased by 117 tons. The decline in soybean production in 2015 was mainly due to a decrease in the harvested area of 673 ha. Meanwhile, the need for soybeans for needs in Bengkulu Province is still imported from other regions such as Java and Lampung Province.

Ultisols are soils that have soil acidity, organic matter, and macronutrients as well as low availability of $\mathrm{P}$ (Fitriatin et al., 2014), cation exchange capacity (CEC), base saturation, and low organic $\mathrm{C}$, and high aluminum content (Mulyani et al., 2010) Due to the high rainfall that occurs in the territory of Indonesia, it can cause high levels of nutrient leaching, especially nitrogen base $(\mathrm{N})$ in the soil. Ultisol is one type of soil that can be used for soybean cultivation but has many limitations on fertility. To overcome the resistance of Ultisol fertility, it can be done by fertilizing organic and inorganic fertilizers.

Bokashi is an organic fertilizer produced through fermentation with the addition of an active ingredient in the form of Effective Microorganism-4 (EM-4). Simarmata \& Hamdani (2003) stated that the fermented organic matter with the addition of EM-4 
can be used as organic fertilizer. The use of bokashi fertilizer can improve the physical, chemical, and biological properties of the soil, and increase crop production and crop yield quality. Arimaya (2007) also stated that phosphate plays an important role in stimulating the formation of flowers, fruits, and seeds. The $\mathrm{P}$ element contained in the manure can accelerate plant growth to provide a better number of productive branches and the number of pods. The results of Wahyuni's research (2007) showed that the application of Bokashi fertilizer had a significant effect on Bokashi at 3, 4, 5, and 6 weeks after planting (wap). Bokashi fertilizer can stimulate plant growth and provide a rapid effect on plant growth. According to Musnamar (2003), the application of bokashi fertilizer also has a significant effect on plant dry weight. This fact is also thought to be influenced by the content of microorganisms contained in bokashi fertilizer, namely photosynthetic bacteria, lactic acid bacteria, yeast, and Actinomycetes. Meanwhile, the results of Fathi et al. (2014) showed that the best dose that could increase growth, yield components, and quality of soybean seed yield was the bokashi dose of $300 \mathrm{~g} \mathrm{plant}^{-1}$.

It is known that inorganic fertilizers $\mathrm{N}, \mathrm{P}, \mathrm{K}$ function as an addition to nutrients in the soil and plant nutrients. The benefits of inorganic fertilizers in general are that they provide nutrients in a relatively faster time, produce available nutrients that can be directly absorbed by plants, are practical, and are available in large quantities. The most abundant or dominant elements in inorganic fertilizers are elements of N, P and K. NPK fertilizers are also called compound fertilizers because they contain more than 2 main nutrients, with nutrient content of $\mathrm{N}(16 \%)$ in the form of $\left(\mathrm{N}_{2} \mathrm{O}\right), \mathrm{P}(16 \%)$ in the form $\left(\mathrm{P}_{2} \mathrm{O}_{5}\right)$, and $\mathrm{K}(16 \%)$ in the form $\left(\mathrm{K}_{2} \mathrm{O}\right)$. However, the presence of excess $\mathrm{N}$ elements can cause delays in plant maturity due to excessive vegetative growth, weak stems and easy to collapse and plants become susceptible to disease (Hardjowigeno, 2010).

This study aims to determine the appropriate dose of Bokashi fertilizer on the growth and yield of soybeans on Ultisol.

\section{MATERIALS AND METHODS}

The research was carried out in December 2018April 2019 in Medan Baru, Kandang Limun Village, Muara Bangkahulu District, Bengkulu City at an altitude of $\pm 10 \mathrm{~m}$ above sea level.

This study used a randomized completely block design (RCBD) with a single factor. The spacing used was $30 \mathrm{~cm} \times 30 \mathrm{~cm}$ with a plot size of $2 \mathrm{~m} \times 2 \mathrm{~m}$ in 15 plots and each plot was given a dose of $150 \mathrm{~g}$ of NPK fertilizer. Two weeks before planting, the plots were fed with Bokashi manure for the predetermined doses, namely: $0 \mathrm{~kg}$ plot $^{-1}, 10 \mathrm{~kg} \mathrm{plot}^{-1}, 14 \mathrm{~kg} \operatorname{plot}^{-1}$, $18 \mathrm{~kg} \mathrm{plot}^{-1}$, and $22 \mathrm{~kg} \mathrm{plot}^{-1}$. The map made measuring 2 $\mathrm{m} \times 2 \mathrm{~m}$.

Bokashi cow dung is made by adding fine manure with bio activator EM-4 which has been diluted with a concentration of $10 \mathrm{~mL} \mathrm{~L}-1$. Next, the manure is poured with a solution that has been diluted slowly and evenly to form a dough. After that, it is put into a drum or large plastic for further fermentation at a temperature of $40-500$ by closing it tightly. The fermentation process lasts 10-14 days and is characterized by black, friable, not hot, and odorless bokashi (Deptan, 2006; Maslikha, 2001).

Soybean planting is planted by inserting soybean seeds in planting holes made $3 \mathrm{~cm}-4 \mathrm{~cm}$ deep with a spacing of $30 \mathrm{~cm} \times 30 \mathrm{~cm}$. Each planting hole is inserted 2-3 seeds that have been mixed with Rhizobium then covered with thin soil. NPK fertilization was carried out at the time of planting and was given a distance of $5-10 \mathrm{~cm}$ from the plant at a dose of $120 \mathrm{~g} \mathrm{plot}^{-1}$. Observations of growth variables were carried out on 7 sample plants in each plot.

Data collected from soybean growth and yield variables were analyzed using analysis of variance (ANOVA) at 5\% level. Regression analysis was used to determine the best dose of Bokashi fertilizer on soybean growth and yield.

\section{RESULT AND DISCUSSION}

The research land used has a low fertility level, the results of soil analysis in the experimental land analyzed showed a $\mathrm{pH}\left(\mathrm{H}_{2} \mathrm{O}\right)$ of 4.30 , a total Nnutrient content of $0.17 \%$, a P-Bray content of 4.83 ppm, K -dd 0.4 me $/ 100$, C-Organic $1.67 \%$ and soil bulk density $1.16 \mathrm{~g} / \mathrm{cm} 3$. The average air temperature in December, January, February, March, and April, respectively, is $26.52{ }^{\circ} \mathrm{C}, 26.82{ }^{\circ} \mathrm{C}, 27.22{ }^{\circ} \mathrm{C}$, $26.41{ }^{\circ} \mathrm{C}$, and $27.36{ }^{\circ} \mathrm{C}$. In general, the best growth of soybean plants requires an air temperature of 250 $-270^{\circ} \mathrm{C}$ and with full light (at least 10 hours/day). Rainfall in December, January, February, March, and April, respectively, is $612.32 \mathrm{~mm}, 324 \mathrm{~mm}, 186.48$ $\mathrm{mm}, 256.5 \mathrm{~mm}$, and $484.5 \mathrm{~mm}$. To be able to grow and provide high yields soybeans require rainfall between 100-200 $\mathrm{mm}$. Soybean plants can grow at an altitude of 0-900 $\mathrm{m}$ above sea level (Adisarwanto, 2010).

In general, soybean plants grew very well, namely $95 \%$ of the population, soybean growth until the age of 2 weeks after planting grew evenly even though replanting was carried out on seeds that did not grow. The next phase of soybean growth appears to have differences due to the effect of the dose of Bokashi fertilizer given in each treatment. In this study, the Anjasmoro variety was used where the Bokashi based on the variety ranged from $64-68 \mathrm{~cm}$, but in this study, the Bokashi reached 90-95 cm. 
At the time of the study, soybeans were attacked by grasshoppers (Cailifera), armyworm (Spodoptera litu$\mathrm{ra}$ ), and brown ladybugs (R.linearis Fabr) during vegetative growth so that pests were sprayed with the active ingredient Deltamethrin $25 \mathrm{~g} \mathrm{~L}^{-1}$. Spraying is done once every 2 weeks.

The results of the analysis of diversity showed that the dose of Bokashi fertilizer had a significant effect on the observed variables of plant height and number of leaves, but had no significant effect on the number of productive branches and the number of flowers (Table 1). Bokashi can affect plant height, because Bokashi fertilizer is a fermented organic material that is useful for plants in providing $\mathrm{N}, \mathrm{S}$, and $\mathrm{P}$ elements as well as increasing soil CEC, and plant height (Wibisono \& Basri, 1993).

Table 1. Analysis of variance of the effect of Bokashi fertilizer dose on the observed variables

\begin{tabular}{|c|c|c|c|}
\hline No & Variable & F value & CV $(\%)$ \\
\hline 1 & Plant height & $9.18 *$ & 85.128 \\
\hline 2 & Number of leaves & $10 *$ & 82.706 \\
\hline 3 & Number of flowers & $2.7 \mathrm{~ns}$ & 159.408 \\
\hline 4 & $\begin{array}{l}\text { Number of produc- } \\
\text { tive branches }\end{array}$ & $0.28 \mathrm{~ns}$ & 152.706 \\
\hline 5 & Number of seeds & $1.03 \mathrm{~ns}$ & 241.415 \\
\hline 6 & $\begin{array}{l}\text { Seed weight per } \\
\text { plant }\end{array}$ & $2.08 \mathrm{~ns}$ & 239.647 \\
\hline 7 & Seed weight per & $1.38 \mathrm{~ns}$ & 152.706 \\
\hline 8 & Weight 100 seeds & $0.86 \mathrm{~ns}$ & 139.855 \\
\hline
\end{tabular}

(*) Significantly different ; (ns) Non Significantly Different

The dose of Bokashi fertilizer significantly affected plant height at 3, 4, 5, and 6 wap. This shows that Bokashi fertilizer can stimulate plant growth and provide a rapid effect on plants. Wahyuni's statement (2007), which states that bokashi has a rapid effect on plants because bokashi directly supplies plant food and soil nutrients. Plant height is an important character and is usually used as an indicator of plant growth. Shorter plants are not necessarily less good, even shorter plants are resistant to laying down. Plant height will usually affect the number of leaves on the plant. The dose of Bokashi fertilizer and plant height form a linear curve which means that the plant height will increase with increasing fertilizer dose (Figure 1).

The dose of Bokashi fertilizer had a significant effect on the growth of the number of leaves. In the observation variable, the number of leaves from all treatments showed that the average number of leaves was 21.7 leaves, which was different from the control treatment, which had an average of 20.4 leaves. Linear curve, which means that the higher the dose of
Bokashi fertilizer applied, the higher the growth of the number of leaves (Figure 2).

Fertilizer analysis that has been carried out shows that Bokashi fertilizer has an elemental $\mathrm{N}$ content of $1.23 \%$. The element $\mathrm{N}$ is the most influential nutrient on the growth and development of leaves. The nutrient content of $\mathrm{N}$ in the soil will be utilized by plants in cell division and cell enlargement to form young leaves. The results of research by Lingga \& Marsono (2001) showed that the $\mathrm{N}$ absorbed by plants serves to stimulate the growth of all parts of the plant, especially stems and leaves. The element $\mathrm{N}$ is needed by plants in large quantities, especially during vegetative growth.

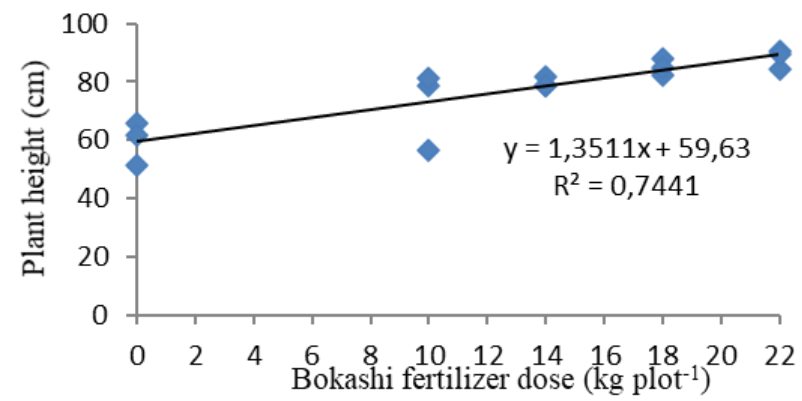

Figure 1. Relationship curve between Bokashi fertilizer dose and plant height

Figure 2. Relationship curve between Bokashi ferti-

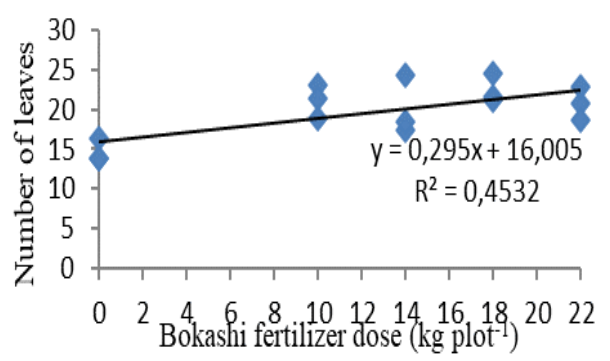

lizer dose and number of leaves

Samuli et al. (2012) also stated that giving Bokashi was able to increase the number of trifoliate leaves. The $\mathrm{P}$ element contained in Bokashi can accelerate plant maturation so that it can provide a large number of trifoliate leaves. Furthermore, the analysis of variance that has been carried out shows that the dose of Bokashi given has no significant effect on the number of flowers and the number of productive branches. This shows that the positive effect of Bokashi fertilizer is not applied to the number of branches and the number of flowers, but rather to the plant height and root length. The description of the Anjasmoro variety shows that the branching of soybean plants is $2.9-5.6$. The number of branches pro- 
duced in this study corresponds to the description. However, the results of data analysis showed that the dose of Bokashi given had no significant effect on the number of branches. The essential nutrients from the decomposition are used mainly for plant height growth and root growth, not for the growth of the number of plant branches (Wididana \& Wigenasantara, 1997).

One of the reasons why the number of flowers has no effect is thought to be because the flowering phase of soybean plants is strongly influenced by the availability of water. In the Bokashi fertilizer analysis, the nutrient content of $\mathrm{N}$ and $\mathrm{P}$ was found to be $1.23 \%$ and $0.45 \%$ so that the flowering process and the formation of productive branches were not optimal due to the lack of availability of $\mathrm{N}$ and $\mathrm{P}$ nutrients and the availability of water itself. The effect of Bokashi on soil physical properties is through the formation of soil aggregates to improve soil structure (Sarief, 1994). Good soil structure will increase the ability of the soil to hold water, improve soil aeration and drainage

Productivity is determined by several components including the number of seeds per plant, seed weight per plant, the weight of 100 seeds, and weight of seeds per plot, but the results of the analysis of variance showed that the dose of Bokashi given had no significant effect on the component variables.

Sudarkoco (1992) stated that the application of organic matter combined with inorganic fertilizers gave higher yields than when using only organic materials or inorganic fertilizers alone. However, the Bokashi dose treatment in this study did not have a significant effect on each outcome component. The presence of EM-4 as a Bokashi element should be very useful, considering how EM-4 synergistically works in the soil to increase soil fertility, both physically, chemically, and biologically so that it can increase plant growth and development as well as increase soil and plant productivity (Wididana \& Higa , 1993). Triyono (2007) also stated that the number of pods was largely determined by the number of empty pods. The number of pods is the same as the formation of fruit in horticultural plants which is largely determined by three main things, namely pollination, plant nutrition, and flower loss. Plants need a certain level of moisture over time and sufficient nutrients, but if the plant contains too much water in the soil it will also affect the process of seed formation in the pod.

In this study, the dose of Bokashi fertilizer also had no significant effect on the number of seeds per plot and the number of 100 seeds because it was assumed that the variety affected the yield. In the description of the variety, the yield of 100 seeds was $14.8-15.3 \mathrm{~g}$, in this study the weight of 100 seeds was the same as the weight of 100 seeds in the description, which was 9.81 - 15.24, however, the ANOVA analysis showed no effect. on the dose of Bokashi fertilizer. It is suspected that there is a genetic influence from the dominant variety, which is also assisted by a suitable growing environment so that superior varieties with higher yields are obtained. This is by Gabesius et al. (2006), which states that varieties play an important role in the development of soybean cultivation because achieving high productivity is largely determined by the yield potential of the superior varieties planted. Simarmata \& Hamdani (2003), explained that Bokashi can be used as organic fertilizer to fertilize the soil and increase plant growth and production. However, it is also suspected that due to weather factors, rainfall that exceeds the maximum limit of the various causes the seeds in the pods at the time of generative to rot and consequently few good and good seeds can be taken. Likewise with the weight of seeds per plot. The variety description also shows the yield per hectare, which is $2.03-2.25$ tons $\mathrm{ha}^{-1}$. However, in this study the dose of Bokashi fertilizer could not exceed the yield in the description, the yield obtained was only 1.58 tons ha ${ }^{-1}$.

\section{CONCLUSION}

The results of this study indicate that the optimum dose of Bokashi was not found in the growth component and yield component variables.

\section{References}

Adie, M. dan Krisnawati, A. 2007. Biologi Tanaman Kedelai. Balai Penelitian Kacang-kacangan dan Umbi-umbian (BALITKABI). Malang

Adisarwanto, T. (2010). Strategi peningkatan produksi kedelai sebagai upaya untuk memenuhi kebutuhan di dalam negeri dan mengurangi impor. Pengembangan Inovasi Pertanian, 3(4), 319-331.

BPS (2015). Produksi Tanaman Pangan Provinsi Bengkulu (Angka Ramalan II 2015) Badan Resmi Statistik BPS Provinsi Bengkulu, Berita Resmi Statistik BPS Provinsi Bengkulu,. NO. 60/11/17IX, 28 Januari 2019

BPS. (2000). Indonesia Statistical Yearbook of 2000. Biro Pusat Statistik . Jakarta

Departemen Pertanian. (2001). Program Pembangunan Pertanian 2001-2004. Departemen Pertanian, Jakarta.

Fathi H. R., Sumade, Nuraini A. (2014). Pengaruh pupuk $\mathrm{P}$ dan Bokashi terhadap pertumbuhan, komponen hasil dan kualitas hasil benih kedelai (Glycine max L. (Merrill)). Agric. Sci. $J ., 1(4), 254-261$.

Fitriatin, B. N., Yuniarti, A., Turmuktini, T. \& Ruswandi, F. K. (2014). The effect of phosphate solubilizing microbe producing growth regula- 
tors on soil phosphate, growth and yield of maize and fertilizer efficiency on Ultisol. Eurasian Journal of Soil Science, 3(2), 101-107.

Gabesius, Y. O., Siregar, L. A. M. \& Husni, Y. (2012). Respon pertumbuhan dan produksi beberapa varietas kedelai (Glycine max (L.) Merrill) terhadap pemberian pupuk Bokashi. Jurnal Agroekoteknologi Universitas Sumatera Utara, 1 (1). 220-236. DOI: 10.32734/jaet.v1i1.672.

Hardjowigeno, S. (2010). Ilmu Tanah. Akademika Pressindo, Jakarta.

Lingga, P. \& Marsono. (2001). Petunjuk Penggunaan Pupuk. Penebar Swadaya, Jakarta.

Mayadewi, N.N.A. (2007). Pengaruh jenis pupuk kandang dan jarak tanam terhadap pertumbuhan dan hasil jagung manis. AGRITROP, 26(4), 153-159.

Mulyani, A., Rachman, A. \& Dairah, A. (2009). Penyebaran Lahan Masam, Potensi dan Ketersediaannya untuk Pengembangan Pertanian. Balai Penelitian Tanah, Bogor.

Musnamar, E. I. (2003). Pupuk Organik Padat: Pembuatan dan Aplikasinya. Penebar Swadaya, Jakarta.

Pusat Penelitian dan Pengembangan Tanaman Pangan. (2012). Pengembangan Teknologi Kedelai di Beberapa Daerah. Berita Puslitbangtan. No.51 Oktober 2012.

Samuli, L. O., Karimuna, L. \& Sabaruddin, L. (2012).
Produksi kedelai (Glycine max L. Merrill) pada berbagai dosis bokashi kotoran sapi. Jurnal Berkala Agronomi, 1(2), 145-147.

Sarief, E.S. (1994). Kesuburan dan Pemupukan Tanah Pertanian. Pustaka Buana, Bandung.

Simarmata, T. \& Hamdani, J. S. (2003). Efek kombinasi jenis pupuk organik dengan Bionutrisi terhadap pertumbuhan dan hasil tanaman jahe (Zingiber officinale Rosc.) pada Inceptisols di Garut. Bionatura, 5(1), 29-37.

Sudarkoco, S. (1992). Penggunaan bahan organik pada usaha budidaya tanaman lahan kering serta pengelolaannya. Institut Pertanian Bogor, Bogor.

Suprapto. (2004). Bertanam Kedelai. Penebar Swadaya, Jakarta.

Triyono, K. (2012). Pengaruh sistem pengolahan tanah dan mulsa terhadap konservasi sumber daya tanah. Innofarm, 6(1), 11-21.

Wahyuni, E. (2007). Menakar efektivitas kompos dan bokashi. Diunduh dari http://www. sintesa. or. id/index. php.

Wibisono, A. \& Basri, M. (1993). Pemanfaatan limbah organik untuk pupuk. Bul. Kyusei Nature Farming, 2.

Wididana, G. N. \& Wigenasantana, M. S. (1997). Aplication of Effective Micoorganism and Bokashi on Nature Farming. Indonesia Kyusei Nature Farming Societes, Jakarta. 